\title{
Investigating Life Quality of the Department of Computer Education and Instructional Technologies (CEIT) Students in Terms of Various Variables
}

\author{
Recep ÖZ ${ }^{1}$ \\ ${ }^{1}$ Department of Computer Education and Instructional Technology, Faculty of Education, Erzincan Binali \\ Yildirim University, Erzincan, Turkey \\ Correspondence: Recep ÖZ, Department of Computer Education and Instructional Technology, Faculty of \\ Education, Erzincan Binali Yildirim University, Erzincan, Turkey. E-mail: recepoz@erzincan.edu.tr
}

Received: April 30, 2021

Accepted: June 14, $2021 \quad$ Online Published: June 24, 2021

doi:10.5539/jel.v10n4p156

URL: https://doi.org/10.5539/jel.v10n4p156

\begin{abstract}
The purpose of the study was to analyze the life quality of CEIT (Computer Education and Instructional Technologies) students according to their perception of gender, age, health status and level of income. The data were collected from the students studying at the third and fourth grades in CEIT undergraduate programs of Education Faculties affiliated to two different state universities. Among these students, 129 were third grade and 44 were fourth grade students. 86 of the students were female and 87 were male. While there were 34 students with a current disease, the number of students without a current disease was 139. Students' perception of family income was at medium and low levels. 123 students who had the perception that their family had a medium level of income and 50 students who had the perception that their family had a low level of income were within the scope of the study. The World Health Organization Quality of Life Scale-Short Form (WHOQL-BREF) was used as the measurement tool. The scale adapted into Turkish included 29 items and five sub-dimensions. In terms of the variable of gender, physical health life quality perception of the students was found to be different in favor of female students. It was determined that the perception of physical health quality of life did not differ between students according to the presence of a current disease and family income. No significant difference was found in psychological life quality perceptions of the students in terms of their gender, current disease and level of income. However, the difference between the scores related to the psychological sub-dimension were found to be significant according to the common effect of gender-health, gender-income and gender-health-income perceptions. The social relations life score average of male students was found to be higher rather than the average score of females, and moreover, average score of the students with low-income perception was found to be higher rather than the average score of students with a perception of medium level of income. The perception of social relations life quality of students with low-income perception and without a current disease was determined to be higher rather than the life quality perceptions of the students with low-income perception. It was determined that the age of CEIT students was not a significant predictor of their perceptions related to physical health, and psychological and environmental life quality. However, the variable of age was specified to be a significant predictor of students' perception on social relations quality of life.
\end{abstract}

Keywords: computer, instructional technologies, ceit, life quality, student perceptions

\section{Introduction}

Rapidly developing communication and computer technology have appeared in any areas of life and facilitated our life. It is inevitable to integrate the developments in information and communication with instructional programs in order to reach the modern education level. Within the framework of the program related to restructuring of Education Faculties initiated by the Council of Higher Education in 1997, teachers who carry on duties in the field of information technologies teaching have started to be trained within the body of "Computer Education and Instructional Technologies Department" (CEIT). These teachers who are defined as individuals who provide computer-related education to students or adults at educational institutions take the courses of general culture, field knowledge and teaching profession knowledge during their undergraduate education. On the other hand, information technology teachers have started to work in Ministry of National Education (MNE) institutions for the maintenance, repair and updating of school Information and Communication Technologies 
(ICT) resources, as well as overcoming the problems of teachers and administrators related to the use of ICT and instructional ICT since 2000s (Deryakulu \& Olkun, 2007; Deryakulu, 2008; Samsa, Bardakc1, Alakurt, \& Akyüz, 2010; Eren \& Uluuysal, 2012; Keser \& Çetinkaya, 2013). With the increase and diversification of school ICT resources as well as the dissemination of interactive smart boards (ISB), computers and tablets in classrooms with the Project of Increasing Opportunities and Improving Technology (FATIH) Project in 2010s, the responsibilities information technology teachers have assumed in the system for a long time seem to be integrated with the role of an information technologies guidance counselor (MEB General Directorate of Innovation and Instructional Technologies, 2012). Universities contribute upon the development of human resources through teaching and improving the life quality of individuals through research and consultancy (Kabeta, 1999, as cited in Buluş, 2005). Quality of life is defined as individuals' perceiving their position in life in relation to their goals, expectations, standards and interests within the framework of culture and value systems they live in. It is a broad concept that is influenced in a complex way by individuals' physical health, psychological state, beliefs, social relationships and relationship with their surrounding (WHO, 1997). It is a broad concept that is influenced in a complex way by individuals' physical health, psychological state, beliefs, social relationships and relationship with their environment (WHO, 1997). University students reflect a youth culture influenced by different cultures. They are sometimes possible to experience emotional difficulties arising from school, social life and themselves (Rui, 1997; Erdem \& İşbaşı, 2001). In addition to the individual differences and needs of students, different problems, expectations or the sense of pleasure arisen from faculty life can affect the faculty culture positively or negatively (Argon \& Kösterelioğlu, 2009). It is an undeniable fact that there are many positive and negative factors affecting the life quality of individuals and university students. The social and individual importance of education for individuals to reach the level of life they want is agreed by anyone (Numanoğlu \& Şen, 2007). It is known that increasing life quality of students contributes upon achieving much better results in education (Eriş \& Anıl, 2015). It is a fact that the effects of the services and conditions provided by the university are remarkable factors in students' feeling themselves as part of the university (Sönmezoğlu et al., 2020). In addition to the situations individuals and students experience, opportunities offered by their surrounding have a great effect upon their perceiving the quality of life. School life quality is generally defined as the happiness of students and their interest in school life (Newcomb, Bentler, \& Collins, 1986; Karatzias, Power, \& Swanson, 2001). The fact related to the time students spend at school as fun or boring has effect upon both their learning and out-of-school period (Fraser, 2012; Linnakylä, 1996; Malin \& Linnakylä, 2001). Therefore, it is considered as an efficient factor in terms of individuals' perceiving their own quality of life. Increasing the perceived life quality of students also means increasing the quality of education. In a previous study, it has been determined that perceptions of students towards the cultural environment of school is efficient upon their achievement (Marcoulides, Heck, \& Papanastasiou, 2005). There is a positive relationship between students' low school satisfaction, individual problems and lack of motivation and school achievements (Porter, 1994; Baker, 1998). Furthermore, low school satisfaction causes negative results such as alienation and displeasure from school (Fine, 1986). The increase in level of life quality contributes upon the increase in level of happiness (Akyüz, Yaşartürk, Aydın, Zorba, \& Türkmen, 2017). The quality of life is undoubtedly affected by a large number of variables. When the literature is reviewed, it is determined that gender as well as economic problems are possible to be efficient upon some dimensions of life quality (Yıldırım \& Hacıhasanoğlu, 2011). Besides, experiencing health problems and the perception related to level of income is possible to be considered in this context. In this respect, the relationship life quality of CEIT students and their perception of sex, age, health status and level of income was tried to be revealed.

\subsection{Purpose of the Study}

It was aimed to analyze life quality of CEIT students according to the perception of gender, age, health status and level of income. For this purpose, answers to the questions below was sought:

1) Do life quality perceptions of CEIT students related to physical health, psychological, social relationships and surrounding differ according to gender, current disease and level of income?

2) Is age a significant predictor of CEIT students' life quality perceptions related to physical health, psychological, social relationships and surrounding?

\section{Method}

\subsection{Study Group}

The study group included the third and fourth grade students studying at Computer Education and Instructional Technology Teaching department of educational faculties affiliated to two different state universities in Eastern Anatolia Region. 129 of the students whose data were collected on the basis of voluntary participation were third 
grade students and 44 were fourth grade students.

\subsection{Measurement Tool}

The World Health Organization Quality of Life Scale-Short Form was used as the measurement tool (WHOQOL-BREF). The scale adapted into Turkish included 29 items and five sub-dimensions. The scale reflected the subjective appearance of individuals and did not have a total score. Each sub-dimension was important on its own (Eser, Fidaner, Fidaner, Eser, Elbi, \& Göker, 1999). These dimensions were Physical Health (PH), Psychological Health, Social Relationships (SR) and Environment as well as General Health. In this study, the first dimension related to general health was not taken into assessment. Five-point Likert as very poor (1), slightly poor (2), neither good nor poor (3), quite good (4) and very good (5) was used in the scale. The raw scores obtained in this method were later converted into a percentage system as reported in the scale instruction, and analysis and evaluations were made accordingly.

Table 1. Internal consistency coefficients related to WHOQOL-BREF sub-dimensions

\begin{tabular}{lllll}
\hline Sub-dimension & $\mathrm{N}$ & Number of Items & Adapted Scale (Eser et al., 1999) & Current study \\
\hline PH & 173 & 7 & .83 & .74 \\
Psychological & 173 & 6 & .66 & .81 \\
SR & 173 & 3 & .53 & .52 \\
Environment & 173 & 8 & .73 & .76 \\
\hline
\end{tabular}

The internal consistency coefficients calculated according to the current application results of the scale and adapted scale were presented in Table 1. Whereas the internal consistency coefficients of PH, Psychological and Environment sub-dimensions were at a good level, the internal consistency coefficient for SR sub-dimension which was similar to the adapted scale was found to be weak. According to K1lıç (2016), it was possible to mention that the scale had low reliability in this sub-dimension.

\subsection{Statistical Analysis}

Within the scope of statistical analysis, whereas factorial ANOVA test was performed in independent groups for the first research question, simple linear regression analysis was performed in addition to correlation analysis in order to answer the second research question (Büyüköztürk, 2016; Can, 2014).

\section{Findings}

The distribution of the participants according to their perception of gender, having a current disease and level of income was presented in Table 2. 86 of the students were female and 87 were male. Whereas there were 34 students with a current disease, the number of students without a current disease was 139. Students' perception of family income was at medium and low levels. Within the scope of the study, there were 123 students with the perception of medium-level family income and 50 students with the perception of a low-level family income.

Table 2. Distribution of participants according to gender, current disease and level of income

\begin{tabular}{lll}
\hline Variable & Dimensions & $\mathrm{N}$ \\
\hline Gender & Female & 86 \\
& Male & 87 \\
Current Disease & Presence of current disease & 34 \\
& Non-presence of current disease & 139 \\
Level of Income & Low & 50 \\
& Medium & 123 \\
\hline
\end{tabular}

The descriptive statistics related to the physical health quality of life perceptions of the participants according to gender, current disease and level of income were presented in Table 3. The average score for physical health quality of life perception of students was 55.76. Whereas the group with the lowest perception of physical health quality of life included males with a current disease and low-income perception ( $\bar{X}=30.39)$, the group with the highest perception of physical health quality of life included female students with a current disease and low-income perception $(\bar{X}=70.59)$. 
Table 3. The descriptive table related to participants' perceptions of physical health quality of life according to gender, current disease, and level of income

\begin{tabular}{|c|c|c|c|c|c|}
\hline Gender & Presence of a current disease & Level of income & Mean & Std. Deviation & $\mathrm{N}$ \\
\hline \multirow[t]{9}{*}{ Female } & \multirow[t]{3}{*}{ Presence of current disease } & Low & 70.59 & 0.00 & 5 \\
\hline & & Medium & 59.93 & 13.28 & 16 \\
\hline & & Total & 62.47 & 12.41 & 21 \\
\hline & \multirow[t]{3}{*}{ No current disease } & Low & 55.88 & 3.40 & 4 \\
\hline & & Medium & 60.08 & 14.37 & 61 \\
\hline & & Total & 59.82 & 13.97 & 65 \\
\hline & \multirow[t]{3}{*}{ Total } & Low & 64.05 & 8.02 & 9 \\
\hline & & Medium & 60.05 & 14.07 & 77 \\
\hline & & Total & 60.47 & 13.58 & 86 \\
\hline \multirow[t]{9}{*}{ Male } & \multirow[t]{3}{*}{ Presence of current disease } & Low & 30.39 & 14.61 & 6 \\
\hline & & Medium & 60.50 & 27.11 & 7 \\
\hline & & Total & 46.61 & 26.47 & 13 \\
\hline & \multirow[t]{3}{*}{ No current disease } & Low & 58.66 & 16.79 & 35 \\
\hline & & Medium & 45.85 & 20.61 & 39 \\
\hline & & Total & 51.91 & 19.84 & 74 \\
\hline & \multirow[t]{3}{*}{ Total } & Low & 54.52 & 19.20 & 41 \\
\hline & & Medium & 48.08 & 22.02 & 46 \\
\hline & & Total & 51.12 & 20.87 & 87 \\
\hline \multirow[t]{9}{*}{ Total } & \multirow[t]{3}{*}{ Presence of current disease } & Low & 48.66 & 23.40 & 11 \\
\hline & & Medium & 60.10 & 17.91 & 23 \\
\hline & & Total & 56.40 & 20.23 & 34 \\
\hline & \multirow[t]{3}{*}{ No current disease } & Low & 58.37 & 15.93 & 39 \\
\hline & & Medium & 54.53 & 18.35 & 100 \\
\hline & & Total & 55.61 & 17.74 & 139 \\
\hline & \multirow[t]{3}{*}{ Total } & Low & 56.24 & 18.03 & 50 \\
\hline & & Medium & 55.57 & 18.33 & 123 \\
\hline & & Total & 55.76 & 18.19 & 173 \\
\hline
\end{tabular}

The results of the factorial ANOVA test in independent groups related to the perception of physical health quality of life according to gender, current disease and level of income were presented in Table 4. The analysis results indicated that the difference between perceptions of physical health quality of life according to gender variable was significant $\left[\mathrm{F}_{(1-165)}=10.419, \mathrm{p}<.01, \eta^{2}=.059\right]$. It was noticed that the average score $(\bar{X}=51.12)$ of male students in this group was lower than the average of female students $(\bar{X}=60.47)$. On the other hand, there was no significant difference between perceptions of physical quality of life according to the perceptions of current disease $\left[\mathrm{F}_{(1-165)}=.004, \mathrm{p}>.05\right]$ and level of income $\left[\mathrm{F}_{(1-165)}=.470 \mathrm{p}>.05\right]$. According to the analysis results, whereas common effect of gender-health $\left[\mathrm{F}_{(1-165)}=3.169 \mathrm{p}>.05\right]$, gender-level of income $\left[\mathrm{F}_{(1-165)}=2.258, \mathrm{p}>.05\right]$ and health-level of income $\left[\mathrm{F}_{(1-165)}=3.145, \mathrm{p}>.05\right]$ was determined to be insignificant, the common effect of gender-health-level of income was found to be significant $\left[\mathrm{F}_{(1-165)}=13.333, \mathrm{p}<.01, \eta^{2}=.075\right]$. Whereas the average score of males with low-income perception $(\bar{X}=30.39)$ was at a very low level, the average score of females was found to be much higher $(\bar{X}=70.59)$. Furthermore, the perception of physical health quality of life $(\bar{X}=45.85)$ of male students with a medium level of income perception and without a current disease was significantly lower rather than perception of physical health life quality of female students $(\bar{X}=60.08)$. 
Table 4. Factorial ANOVA test results for independent groups for the perception of quality of life related to physical health according to gender, current disease and level of income perception

\begin{tabular}{lllllll}
\hline Source & Type III Sum of Squares & df & Mean Square & F & $\mathrm{p}$ & $\eta^{2}$ \\
\hline Corrected Model & $10654.667^{\mathrm{a}}$ & 7 & 1522.095 & 5.428 & $.000^{* *}$ & .187 \\
Intercept & 218742.837 & 1 & 218742.837 & 780.010 & $.000^{* *}$ & .825 \\
Gender & 2921.889 & 1 & 2921.889 & 10.419 & $.002^{* *}$ & .059 \\
Health & .998 & 1 & .998 & .004 & .952 & .000 \\
Level of income & 131.683 & 1 & 131.683 & .470 & .494 & .003 \\
Gender * Health & 888.780 & 1 & 888.780 & 3.169 & .077 & .019 \\
Gender * Level of income & 633.282 & 1 & 633.282 & 2.258 & .135 & .014 \\
Health * Level of income & 881.994 & 1 & 881.994 & 3.145 & .078 & .019 \\
Gender * Health * Level of income & 3739.053 & 1 & 3739.053 & 13.333 & $.000^{* *}$ & .075 \\
Error & 46271.949 & 165 & 280.436 & & & \\
Total & 594878.893 & 173 & & & & \\
Corrected Total & 56926.616 & 172 & & & & \\
\hline
\end{tabular}

Note. a. $\mathrm{R}$ Squared $=.187$ (Adjusted R Squared $=153$ ); ${ }^{*} \mathrm{p}<.05 ;{ }^{* *} \mathrm{p}<.01$.

The descriptive statistics related to the psychological quality of life perceptions of the participants according to gender, current disease and level of income were presented in Table 5. The average score related to the students' perception of psychological quality of life was determined to be 64.64. It was understood that the group with the lowest perception of psychological quality of life included males with a current disease and a low-income perception $(\bar{X}=32.91)$, and the group with the highest perception of medium level of income $(\bar{X}=79.37)$ included males with a current disease.

Table 5. The descriptive table related to the participants' perceptions of psychological quality of life according to gender, current disease and level of income

\begin{tabular}{|c|c|c|c|c|c|}
\hline Gender & Presence of a current disease & Level of Income & Mean & Std. Deviation & $\mathrm{N}$ \\
\hline \multirow[t]{9}{*}{ Female } & \multirow[t]{3}{*}{ Presence of current disease } & Low & 72.22 & 0.00 & 5 \\
\hline & & Medium & 54.51 & 25.60 & 16 \\
\hline & & Total & 58.73 & 23.48 & 21 \\
\hline & \multirow[t]{3}{*}{ No current disease } & Low & 69.44 & 10.64 & 4 \\
\hline & & Medium & 66.03 & 10.98 & 61 \\
\hline & & Total & 66.24 & 10.91 & 65 \\
\hline & \multirow[t]{3}{*}{ Total } & Low & 70.99 & 6.68 & 9 \\
\hline & & Medium & 63.64 & 15.70 & 77 \\
\hline & & Total & 64.41 & 15.16 & 86 \\
\hline \multirow[t]{9}{*}{ Male } & \multirow[t]{3}{*}{ Presence of current disease } & Low & 36.11 & 32.91 & 6 \\
\hline & & Medium & 79.37 & 2.71 & 7 \\
\hline & & Total & 59.40 & 30.96 & 13 \\
\hline & \multirow[t]{3}{*}{ No current disease } & Low & 67.78 & 17.24 & 35 \\
\hline & & Medium & 64.10 & 12.74 & 39 \\
\hline & & Total & 65.84 & 15.04 & 74 \\
\hline & \multirow[t]{3}{*}{ Total } & Low & 63.14 & 22.73 & 41 \\
\hline & & Medium & 66.43 & 12.99 & 46 \\
\hline & & Total & 64.88 & 18.20 & 87 \\
\hline \multirow[t]{9}{*}{ Total } & \multirow[t]{3}{*}{ Presence of current disease } & Low & 52.53 & 29.96 & 11 \\
\hline & & Medium & 62.08 & 24.20 & 23 \\
\hline & & Total & 58.99 & 26.13 & 34 \\
\hline & \multirow[t]{3}{*}{ No current disease } & Low & 67.95 & 16.59 & 39 \\
\hline & & Medium & 65.28 & 11.67 & 100 \\
\hline & & Total & 66.03 & 13.23 & 139 \\
\hline & \multirow[t]{3}{*}{ Total } & Low & 64.56 & 20.93 & 50 \\
\hline & & Medium & 64.68 & 14.75 & 123 \\
\hline & & Total & 64.64 & 16.71 & 173 \\
\hline
\end{tabular}

The results of the factorial ANOVA test in independent groups related to the perception of psychological quality of life according to gender, current disease and level of income were presented in Table 6 . The analysis results 
indicated that the difference between perceptions of physical health quality of life was not significant according to gender $\left[\mathrm{F}_{(1-165)}=1.042, \mathrm{p}>.05\right]$, health $\left[\mathrm{F}_{(1-165)}=2.986, \mathrm{p}>.05\right]$ and level of income $\left[\mathrm{F}_{(1-165)}=1.609, \mathrm{p}>.05\right]$. Furthermore, it was observed that the common effect of gender-health was not significant $\left[\mathrm{F}_{(1-165)}=.278, \mathrm{p}>.05\right]$. On the other hand, the common effects of gender-level of income $\left[F_{(1-165)}=17.406, p<.01, \eta^{2}=.095\right]$, health-level of income $\left[\mathrm{F}_{(1-165)}=5.031, \mathrm{p}<.05, \eta^{2}=.030\right]$ and gender-health-level of income were determined to have a significant effect upon the perception of psychological quality of life $\left[\mathrm{F}_{(1-165)}=17.705, \mathrm{p}<.01, \eta^{2}=.097\right]$. The perception of quality of life related to the psychological sub-dimension was 66.24 in females without a current disease, 58.73 in females with a current disease, 65.84 in males without a current disease and 59.4 in males with a current disease. According to the perception of gender-level of income, it was found that the score related to psychological sub-dimension was higher in females with a low-income perception rather than the other groups (70.99), whereas females with medium level of income perception (63.64) and males with low-income perception (63.13) were found to have lower scores. According to the perception of gender, health and level of income, psychological sub-dimension scores were highest (79.37) in students with a perception of medium level of income and with a current disease, whereas the score was at the lowest level (36.11) in males with a low-income perception and a current disease.

Table 6. Factorial ANOVA test results for independent groups related to perception of psychological quality of life according to gender, current disease and level of income perception

\begin{tabular}{lllllll}
\hline Source & Type III Sum of Squares & df & Mean Square & $\mathrm{F}$ & $\mathrm{p}$ & $\eta^{2}$ \\
\hline Corrected Model & $8895.145^{\mathrm{a}}$ & 7 & 1270.735 & 5.358 & $.000^{* *}$ & .185 \\
Intercept & 290890.772 & 1 & 290890.772 & 1226.561 & $.000^{* *}$ & .881 \\
Gender & 247.154 & 1 & 247.154 & 1.042 & .309 & .006 \\
Health & 708.134 & 1 & 708.134 & 2.986 & .086 & .018 \\
Level of income & 381.560 & 1 & 381.560 & 1.609 & .206 & .010 \\
Gender * Health & 65.848 & 1 & 65.848 & .278 & .599 & .002 \\
Gender * Level of income & 4128.005 & 1 & 4128.005 & 17.406 & $.000^{* *}$ & .095 \\
Health * Level of income & 1193.236 & 1 & 1193.236 & 5.031 & $.026^{*}$ & .030 \\
Gender * Health * Level of income & 4199.008 & 1 & 4199.008 & 17.705 & $.000^{* *}$ & .097 \\
Error & 39131.330 & 165 & 237.160 & & & \\
Total & 770956.790 & 173 & & & & \\
Corrected Total & 48026.475 & 172 & & & & \\
\hline
\end{tabular}

Note. a. $\mathrm{R}$ Squared $=.185$ (Adjusted R Squared $=.151$ ); ${ }^{*} \mathrm{p}<.05 ;{ }^{* *} \mathrm{p}<.01$.

The average and standard deviations in terms of the participants' perceptions of quality of life related to social relationships according to gender, current disease and level of income status were presented in Table 7 . The average score of the students participating into the study for the perception of quality of life related to social relationships was 59.60 according to the hundred percent system. It was understood that the group with the lowest score included females with a current disease and low income perception $(\bar{X}=30.00)$ whereas it was the highest in males with a current disease and perception of medium level of income $(\bar{X}=75.71)$. 
Table 7. The descriptive table related to the participants' perceptions of quality of life according to social relationships in terms of gender, current disease and level of income

\begin{tabular}{|c|c|c|c|c|c|}
\hline Gender & Presence of a current disease & Level of income & Mean & Std. Deviation & $\mathrm{N}$ \\
\hline \multirow[t]{9}{*}{ Females } & \multirow[t]{3}{*}{ Presence of current disease } & Low & 30.00 & 0.00 & 5 \\
\hline & & Medium & 56.25 & 33.84 & 16 \\
\hline & & Total & 50.00 & 31.46 & 21 \\
\hline & \multirow[t]{3}{*}{ No current disease } & Low & 52.50 & 20.62 & 4 \\
\hline & & Medium & 56.07 & 16.96 & 61 \\
\hline & & Total & 55.85 & 17.04 & 65 \\
\hline & \multirow[t]{3}{*}{ Total } & Low & 40.00 & 17.32 & 9 \\
\hline & & Medium & 56.10 & 21.28 & 77 \\
\hline & & Total & 54.42 & 21.40 & 86 \\
\hline \multirow[t]{9}{*}{ Males } & \multirow[t]{3}{*}{ Presence of current disease } & Low & 51.67 & 11.69 & 6 \\
\hline & & Medium & 75.71 & 5.35 & 7 \\
\hline & & Total & 64.62 & 15.06 & 13 \\
\hline & \multirow{3}{*}{ No current disease } & Low & 67.14 & 24.08 & 35 \\
\hline & & Medium & 62.56 & 22.21 & 39 \\
\hline & & Total & 64.73 & 23.07 & 74 \\
\hline & \multirow[t]{3}{*}{ Total } & Low & 64.88 & 23.25 & 41 \\
\hline & & Medium & 64.57 & 21.05 & 46 \\
\hline & & Total & 64.71 & 21.99 & 87 \\
\hline \multirow[t]{9}{*}{ Total } & \multirow[t]{3}{*}{ Presence of current disease } & Low & 41.82 & 14.01 & 11 \\
\hline & & Medium & 62.17 & 29.54 & 23 \\
\hline & & Total & 55.59 & 27.10 & 34 \\
\hline & \multirow[t]{3}{*}{ No current disease } & Low & 65.64 & 23.93 & 39 \\
\hline & & Medium & 58.60 & 19.33 & 100 \\
\hline & & Total & 60.58 & 20.88 & 139 \\
\hline & \multirow[t]{3}{*}{ Total } & Low & 60.40 & 24.16 & 50 \\
\hline & & Medium & 59.27 & 21.51 & 123 \\
\hline & & Total & 59.60 & 22.24 & 173 \\
\hline
\end{tabular}

The results of the factorial ANOVA test in independent groups related to the quality of life in social relations according to gender, current disease and level of income were presented in Table 8 . The results indicated that the difference between life quality perception levels related to the sub-dimension of social relationships in terms of gender $\left[\mathrm{F}_{(1-165)}=9.555, \mathrm{p}<.01, \eta^{2}=.055\right]$ and level of income perception $\left[\mathrm{F}_{(1-165)}=5.985, \mathrm{p}<.01, \eta^{2}=.035\right]$ was significant; however, the difference related to the sub-dimension of health $\left[\mathrm{F}_{(1-165)}=1.496, \mathrm{p}>.05\right]$ was not significant. Whereas the common effect of health and level of income was significant $\left[\mathrm{F}_{(1-165)}=6.487, \mathrm{p}<.05\right.$, $\left.\eta^{2}=.038\right]$, the differences created by other common effects were insignificant. The average social relations life score of male students (64.71) was higher than the average score of females (54.42). The social relations quality of life score average of students with low-income perception (60.4) was higher rather than the average score of students with medium level of income perception (59.27).

Table 8. Factorial ANOVA test results for independent groups related to the perception of social relations quality of life according to gender, current disease and level of income

\begin{tabular}{|c|c|c|c|c|c|c|}
\hline Source & Type III Sum of Squares & $\mathrm{df}$ & $\begin{array}{l}\text { Mean } \\
\text { Square }\end{array}$ & $\mathrm{F}$ & $\mathrm{p}$ & $\eta^{2}$ \\
\hline Corrected Model & $10053.301^{\mathrm{a}}$ & 7 & 1436.186 & 3.159 & $.004^{* *}$ & .118 \\
\hline Intercept & 228781.049 & 1 & 228781.049 & 503.195 & $.000^{* *}$ & .753 \\
\hline Gender & 4344.292 & 1 & 4344.292 & 9.555 & $.002^{* *}$ & .055 \\
\hline Health & 680.246 & 1 & 680.246 & 1.496 & .223 & .009 \\
\hline Level of income & 2721.124 & 1 & 2721.124 & 5.985 & $.015^{*}$ & .035 \\
\hline Gender $*$ Health & 447.647 & 1 & 447.647 & .985 & .323 & .006 \\
\hline Gender * Level of income & 119.931 & 1 & 119.931 & .264 & .608 & .002 \\
\hline Health $*$ Level of income & 2949.485 & 1 & 2949.485 & 6.487 & $.012^{*}$ & .038 \\
\hline Gender * Health * Level of income & 39.554 & 1 & 39.554 & .087 & .768 & .001 \\
\hline Error & 75018.375 & 165 & 454.657 & & & \\
\hline Total & 699500.000 & 173 & & & & \\
\hline Corrected Total & 85071.676 & 172 & & & & \\
\hline
\end{tabular}

Note. a. R Squared $=.118$ (Adjusted R Squared $=.081$ ); ${ }^{*} \mathrm{p}<.05 ;{ }^{* *} \mathrm{p}<.01$. 
In Table 9, the descriptive statistics for students' perceptions of quality of life related to the environment according to gender, current disease and level of income were presented. It was understood that the average score for the participants' perception of the quality of life related to the environment was 45.26 according to the hundred percent system. It was determined that the group with the highest perception of quality of life related to the environment included male students with a medium level of income perception $(\bar{X}=70.00)$, and the lowest group included female students with a low-income perception $(\bar{X}=0.00)$.

Table 9. The descriptive table related to the participants' perceptions of quality of life regarding the environment according to gender, current disease, and level of income

\begin{tabular}{|c|c|c|c|c|c|}
\hline Gender & Presence of a current disease & Level of income & Mean & Std. Deviation & $\mathrm{N}$ \\
\hline \multirow[t]{9}{*}{ Female } & \multirow[t]{3}{*}{ Presence of current disease } & Low & 0.00 & 0.00 & 5 \\
\hline & & Medium & 32.81 & 22.06 & 16 \\
\hline & & Total & 25.00 & 23.87 & 21 \\
\hline & \multirow[t]{3}{*}{ No current disease } & Low & 20.00 & 14.14 & 4 \\
\hline & & Medium & 53.20 & 20.76 & 61 \\
\hline & & Total & 51.15 & 21.86 & 65 \\
\hline & \multirow[t]{3}{*}{ Total } & Low & 8.89 & 13.64 & 9 \\
\hline & & Medium & 48.96 & 22.48 & 77 \\
\hline & & Total & 44.77 & 24.93 & 86 \\
\hline \multirow[t]{9}{*}{ Male } & \multirow[t]{3}{*}{ Presence of current disease } & Low & 17.50 & 11.29 & 6 \\
\hline & & Medium & 70.00 & 17.08 & 7 \\
\hline & & Total & 45.77 & 30.68 & 13 \\
\hline & \multirow[t]{3}{*}{ No current disease } & Low & 48.29 & 20.83 & 35 \\
\hline & & Medium & 43.46 & 17.81 & 39 \\
\hline & & Total & 45.74 & 19.32 & 74 \\
\hline & \multirow[t]{3}{*}{ Total } & Low & 43.78 & 22.49 & 41 \\
\hline & & Medium & 47.50 & 19.99 & 46 \\
\hline & & Total & 45.75 & 21.17 & 87 \\
\hline \multirow[t]{9}{*}{ Total } & \multirow[t]{3}{*}{ Presence of current disease } & Low & 9.55 & 12.14 & 11 \\
\hline & & Medium & 44.13 & 26.78 & 23 \\
\hline & & Total & 32.94 & 28.15 & 34 \\
\hline & \multirow[t]{3}{*}{ No current disease } & Low & 45.38 & 21.90 & 39 \\
\hline & & Medium & 49.40 & 20.14 & 100 \\
\hline & & Total & 48.27 & 20.65 & 139 \\
\hline & \multirow[t]{3}{*}{ Total } & Low & 37.50 & 25.04 & 50 \\
\hline & & Medium & 48.41 & 21.51 & 123 \\
\hline & & Total & 45.26 & 23.05 & 173 \\
\hline
\end{tabular}

The results of the factorial ANOVA test in independent groups related to the perception of quality of life regarding the environment in terms of gender, current disease and level of income were presented in Table 10. Factorial ANOVA results indicated that the difference between life quality perception levels related to the sub-dimension of physical health in terms of gender $\left[\mathrm{F}_{(1-165)}=15.752, \mathrm{p}<.01, \eta^{2}=.087\right]$, health $\left[\mathrm{F}_{(1-165)}=5.850\right.$, $\left.\mathrm{p}<.05, \eta^{2}=.034\right]$ and level of income $\left[\mathrm{F}_{(1-165)}=37.956, \mathrm{p}<.01, \eta^{2}=.187\right]$ were not significant. Quality of life perception related to the environment was higher in male students (45.75) rather than female students (44.77). The quality of life perception of students without a current disease (48.27) was higher rather than the perception of quality of life of students with a current disease (32.94). In terms of the perception of income, the quality of life perception of the students with a medium level of income (48.42) was higher rather than the perception of the students with a low level of income (37.5).

Furthermore, it was determined that the common effect of gender-health $\left[\mathrm{F}_{(1-165)}=3.835, \mathrm{p}>.05\right]$ and gender-level of income $\left[\mathrm{F}_{(1-165)}=.987, \mathrm{p}>.05\right]$ was not significant. On the other hand, it was revealed that the common effects of health-income $\left[\mathrm{F}_{(1-165)}=9.521, \mathrm{p}<.05, \eta^{2}=.55\right]$ and gender-health-level of income upon the perception of quality of life related to the environment were found to be significant $\left[\mathrm{F}_{(1-165)}=9.780, \mathrm{p}<.01, \mathrm{\eta}^{2}=.056\right]$. Whereas the perception of quality of life related to the environment was very low in students with a low-income perception and without a current disease (9.44), it was much higher in students with a current disease and perception of medium level of income (44.13) and students with a low (45.38) and medium (49.4) levels of income perception. According to the common effect of gender-health and level of income, the perception of environment quality of life among female students with a current disease was at the lowest level $(0.00)$ according 
to the hundred percent score, whereas it was at the highest level (70.00) for students with a current disease and perception of medium level of income.

Table 10. Factorial ANOVA test results for independent groups regarding perception of quality of life related to the environment according to the perception of gender, current disease, and level of income

\begin{tabular}{lllllll}
\hline Source & Type III Sum of Squares & df & Mean Square & F & $\mathrm{p}$ & $\eta^{2}$ \\
\hline Corrected Model & $28470.883^{\mathrm{a}}$ & 7 & 4067.269 & 10.662 & $.000^{* *}$ & .311 \\
Intercept & 91159.028 & 1 & 91159.028 & 238.968 & $.000^{* *}$ & .592 \\
Gender & 6008.997 & 1 & 6008.997 & 15.752 & $.000^{* *}$ & .087 \\
Health & 2231.573 & 1 & 2231.573 & 5.850 & $.017^{*}$ & .034 \\
Level of income & 14478.893 & 1 & 14478.893 & 37.956 & $.000^{* *}$ & .187 \\
Gender * Health & 1462.959 & 1 & 1462.959 & 3.835 & .052 & .023 \\
Gender * Level of income & 376.543 & 1 & 376.543 & .987 & .322 & .006 \\
Health * Level of income & 3632.143 & 1 & 3632.143 & 9.521 & $.002^{* *}$ & .055 \\
Gender * Health * Level of income & 3730.841 & 1 & 3730.841 & 9.780 & $.002^{* *}$ & .056 \\
Error & 62942.412 & 165 & 381.469 & & & \\
Total & 445800.000 & 173 & & & & \\
Corrected Total & 91413.295 & 172 & & & & \\
\hline
\end{tabular}

Note. a. R Squared $=.311$ (Adjusted R Squared $=.282$ ); ${ }^{*} \mathrm{p}<.05 ;{ }^{* *} \mathrm{p}<.01$.

The correlation coefficients between the age of CEIT students and their physical health, psychological, social relationships and environmental scores were presented in Table 11. It was determined that the relationship between age and social relationships score was significant $(\mathrm{r}=.220, \mathrm{p}<.01)$, but the relationship between physical health $(\mathrm{r}=.220, \mathrm{p}>.05)$, psychological $(\mathrm{r}=.125, \mathrm{p}>.05)$ and environment $(\mathrm{r}=.075, \mathrm{p}>.05)$ was not significant.

Table 11. Correlation coefficients between the age of CEIT students and their physical health, psychological, social relationships and environmental scores

\begin{tabular}{lllll}
\hline Variables & Age & Physical Health & Psychological Health & Social Relationships \\
\hline Physical Health & .014 & & & \\
Psychological Health & .125 & $.489^{*}$ & & \\
Social Relationships & $.220^{*}$ & $.369^{*}$ & $.553^{*}$ & $.494^{*}$ \\
Environment & .075 & $.413^{*}$ & $.620^{*}$ & \\
\hline
\end{tabular}
Note. ${ }^{*}<.01$

The results of the correlation analysis revealed that the age variable was not a significant predictor of perceptions of physical health, psychological and environmental quality of life in CEIT students. On the other hand, it was determined that there was a positive significant relationship between the age variable and social relationships score. Simple linear regression analysis was performed to determine whether age was a significant predictor of social relationships dimension, and the analysis results were presented in Table 12.

Table 12. Simple linear regression analysis results related to age's predicting the dimension of social relationships

\begin{tabular}{|c|c|c|c|c|c|}
\hline & \multicolumn{2}{|c|}{ Unstandardized Coefficients } & \multicolumn{2}{|c|}{ Standardized Coefficients } & \multirow[b]{2}{*}{ Sig. } \\
\hline Variable & B & Std. Error & Beta & $\mathrm{t}$ & \\
\hline (Constant) & -.652 & 20.450 & & & \\
\hline Age & 2.737 & .926 & .220 & 2.956 & $.004 *$ \\
\hline
\end{tabular}

Note. $\mathrm{R}=.220, \mathrm{p}<.01, \mathrm{R}^{2}=.049$, Durbin-Watson=1.975; * $\mathrm{p}<.01, \mathrm{~F}_{(1-171)}=8.737, \mathrm{p}<.01$.

It was understood that the established regression analysis was significant in general $\left(\mathrm{F}_{(1-171)}=8.737, \mathrm{p}<.01\right)$. Simple linear regression analysis results indicated that age was a significant predictor of social relationships dimension $\left(\mathrm{R}=.220, \mathrm{p}<.01 . \mathrm{R}^{2}=.049\right)$. It was determined that approximately $4.9 \%$ of the variation in the dimension of social relationships was possible to be explained with the variable of age, and the score for the social relationships dimension increased as the age increased. 


\section{Discussion}

Quality of life is possible to be used as a tool to identify groups with physical or mental health problems and to serve as a guide for intervention and follow-on assessment (Gholami et al., 2013).

Students' perceptions of physical health quality of life according to the variable of gender differed in favor of female students. Whereas this result was similar to some research results (Yıldırım \& Hacıhasanoğlu, 2011), it was different from the results of some other researches (Akyüz et al., 2017; Durmuş, Gerçek, \& Çiftçi, 2018). It was determined in a study (Telatar \& Üner, 2020) that physical health quality of life was high in favor of male students. When similar studies were reviewed, it was determined in some studies (Mok \& Flynn, 2002; Marks, 1998) that gender had an indirect effect upon perceptions of school life quality though not strong, and in some studies (Daly \& Defty, 2001) this effect was not statistically significant. Doğanay and Sarı (2007) stated in their study carried out for determining the university life quality of Çukurova University students that there was no significant difference in terms of gender. Salici (2010) who carried out a similar study with the students of School of Physical Education and Sports concluded that there was no statistically significant difference in terms of gender. On the other hand, Low (2000) and Ren (2009) found just as in this study that the physical life perceptions of female students related to university life were significantly different from those of males.

The perception of physical health quality of life did not differ between students according to the presence of a current disease and perception of family income. It was noticed that similar results were obtained in some previous studies (Akyüz et al., 2017). However, in some studies, it was found that level of income increased the quality of life (Aylaz \& Aydın, 2014; Cimete, Gençalp, \& Keskin, 2003; Chou, Lin, Chang, \& Schalock, 2007; Durmuş, Gerçek, \& Çiftçi, 2018; Yıldırım \& Hacıhasanoğlu, 2011; Yazıc1, 2012). Moreover, it was determined that good general health status also increased the physical health quality of life (Telatar \& Üner, 2020). In this respect, it was possible to mention that the results obtained from this study were different.

Psychological quality of life perceptions of students did not differ significantly according to their perception of gender, current disease and level of income. However, the difference between the scores of psychological subdimension was significant according to the common effect of gender-health, gender-income and gender-health-income perceptions. While the perception of quality of life for this dimension was high in males and females without a current disease, it was low in males and females with a current disease. This could be mentioned as an expected result. Previous studies reported that health status affected the perception of life (Telatar \& Üner, 2020). However, it was noticed in terms of gender as an expected result that psychological subdimension score was high in students with a low-income perception and low in females with medium level of income perception. Therefore, further researches were possible to be carried out on this separately. In their study comparing the quality of life of Chinese and Japanese youth, Wang et al. (2000) reported that there was no statistically significant difference between the genders. On the other hand, psychological sub-dimension scores were the highest in students with a perception of medium level of income and a current disease, and the lowest in males with a current disease and perception of low-income level according to gender-health and income perception. It was possible to mention that the perception of disease and low income had negative effect upon male students' perception of psychological life.

Social relationships life score average of male students was higher than females' average score, and social relationships life score average of the students with low-income perception was higher rather than score averages of the students with medium level of income perception. Yazicı (2012), on the other hand, determined that although the majority of the participants had a low level of income, the rate of perception related to level of income was higher rather than that of individuals who perceived as poor.

The social relationships quality of life perception of the students with low-income perception and without a current disease was higher rather than the quality of life perception of the students with a low income perception. This result revealed that health was important in perception of quality of life (Yazıc1, 2012).

Quality of life perception about the environment was higher in male students rather than female students. The perception of the quality of life of the students who had no current disease according to health was higher than the perception of the quality of life of the students with a current disease. According to the perception of income, the quality of life perception of the students with medium-level of income perception about the environment was found to be higher than the perception of the students with low income perception. Yazici (2012) found similar results in his study analyzing the quality of life and depressive states of amputees who did sports and those who did not.

While the perception of quality of life related to the environment was very low in students with low-income perception without a current disease (9.44), it was much higher in students with a current disease but with a 
perception of medium income (44.13) and students with a low (45.38) and medium (49.4) income perception. According to the common effect of gender-health and income, whereas the perception of environmental quality of life among female students with a current disease was at the lowest level (0.00) according to the hundred percent score, it was at the highest level (70.00) for students with a current disease and perception of medium income. Güler (2006) found in the study on patients that depression and quality of life were closely associated, and physical, emotional and social well-being of patients were also negatively affected in patients with decreased life quality. Moreover, Schwenk et al. (2007) found in their study carried out with American football players that physical activity, economic status and social life as the sub-dimensions of life quality decreased in retired professional football players who were exposed to depression. The researcher found that the life quality of retired football players was at a moderate level, and their depression level was mild, and the life quality scores of retired football players were determined to be decreased as their depression levels increased.

The age of CEIT students was not a significant predictor of their perceptions of physical health, psychological and environmental quality of life (Al-Shibani \& Al-Kattan, 2019). However, the variable of age was a significant predictor of students' perception of social relationships quality of life. Students' perception of social relations quality of life increased as the age increased. Similar to the study results of Bensalah et al. (2008), a negative relationship was observed between age and health quality. In some previous studies, it was determined that young patients' quality of life scores were higher than elderly patients (Fujisawa et al., 2000; Balaska et al., 2006). Humar et al. (2003) and Ponton et al. (2001) expressed in their studies that there was no significant difference between individuals' quality of life in terms of age criteria. The results we obtained from our study were consistent with the findings of the studies carried out by Humar et al. (2003) and Ponton et al. (2001). Andre et al. (2017) reported that the physical health scores of the fourth-grade students were significantly higher rather than the first-grade students. Zhang et al. (2012) found significant differences in social relations and psychological health between third-grade students with the lowest score.

\section{References}

Akyüz, H., Yaşartürk, F., Aydın, İ., Zorba, E., \& Türkmen, M. (2017). Üniversite öğrencilerinin yaşam kalitesi ve mutluluk düzeyleri arasındaki ilişkinin incelenmesi. Uluslararası Kültürel ve Sosyal Araştırmalar Dergisi (UKSAD), 3(2), 253-262.

Al-Shibani, N., \& Al-Kattan, R. (2019). Evaluation of quality of life among dental students using WHOQOL-BREF questionnaire in Saudi Arabia: A cross sectional study. Pakistan Journal of Medical Sciences, 35(3), 668. https://doi.org/10.12669/pjms.35.3.213

Andre, A., Pierre, G. C., \& McAndrew, M. (2017). Quality of life among dental students: A survey study. Journal of Dental Education, 81(10), 1164-1170. https://doi.org/10.21815/JDE.017.074

Argon, T., \& Kösterelioğlu, M. (2009). Üniversite öğrencilerinin üniversite yaşam kalitesi ve fakülte kültürüne ilişkin algıları. Elektronik Sosyal Bilimler Dergisi, 8(30), 43-61. Retrieved from https://dergipark.org.tr/en/pub/esosder/issue/6144/82461

Aylaz, R., \& Aydın, S. (2014). Acil ve diğer servislerde görev yapan sağlık çalışanlarının vardiyalı çalışmasının yaşam kalitesi üzerine etkisi. Yıldırım Beyazıt Üniversitesi Hemşirelik e-dergisi, 2(3).

Baker, J. A. (1998). The social context of school satisfaction among urban, low-income, African American students. School Psychology Quarterly, 13(1), 25-44. https://doi.org/10.1037/h0088970

Balaska, A., Moustafellos, P., Gourgiotis, S., Pistolas, D., Hadjiyannakis, E., Vougas, V., \& Drakopoulos, S. (2006). Changes in health-related quality of life in Greek adult patients 1 year after successful renal transplantation. Experimental and Clinical Transplantation: Official Journal of the Middle East Society for Organ Transplantation, 4(2), 521-524.

Bensalah, K., Tuncel, A., Gupta, A., Raman, J. D., Pearle, M. S., \& Lotan, Y. (2008). Determinants of quality of life for patients with kidney stones. The Journal of Urology, 179(6), 2238-2243. https://doi.org/10.1016/j.juro.2008.01.116

Buluş, M. (2005). Pamukkale Üniversitesi öğretim elemanlarında akademik ortam doyum düzeyi. PAU Eğitim fakültesi Dergisi, 15 ,

Büyüköztürk, Ş. (2016). Sosyal bilimler için veri analizi el kitabı (22. Bask1). Ankara: Pegem Akademi.

Can, A. (2014). SPSS ile bilimsel araştırma sürecinde nicel veri analizi (Üçüncü Bask1). Ankara: Pegem Akademi. https://doi.org/10.14527/9786053644484

Chou, Y. C., Lin, L. C., Chang, A. L., \& Schalock, R. L. (2007). The quality of life of family caregivers of adults 
with intellectual disabilities in Taiwan. Journal of Applied Research in Intellectual Disabilities, 20(3), 200-210. https://doi.org/10.1111/j.1468-3148.2006.00318.x

Cimete, G., Gencalp, N. S., \& Keskin, G. (2003). Quality of life and job satisfaction of nurses. Journal of Nursing Care Quality, 18(2), 151-158. https://doi.org/10.1097/00001786-200304000-00009

Daly, P., \& Defty, N. (2001). A Longitudinal Study of Secondary School Students' Attitudes to School Life: Gender and School Gender Influences. Third International, Inter-Disciplinary Evidence-Based Policies and Indicator Systems Conference, July 2001, CEM Centre, University of Durham.

Deryakulu, D. (2008). Bilişim teknolojileri öğretimi ve meslek seçimi. Bilişim teknolojileri öğretiminde sosyo-psikolojik değişkenler. Ankara: Maya Akademi.

Deryakulu, D., \& Olkun, S. (2007). Analysis of computer teachers' online discussion forum messages about their occupational problems. Journal of Educational Technology \& Society, 10(4), 131-142. https://doi.org/10.1501/0003617

Doğanay, A., \& Mediha, S. A. R. I. (2006). Öğrencilerin Üniversitedeki Yaşam Kalitesine Ilişkin Algilarinin Demokratik Yaşam Kültürü Çerçevesinde Değerlendirilmesi (Çukurova Üniversitesi Örneği). Türk Eğitim Bilimleri Dergisi, 4(2), 107-128.

Durmuş, M., Gerçek, A., \& Çiftci, N. (2018). Hemşirelerin yaşam kaliteleri ile tükenmişlik düzeylerinin değerlendirilmesine yönelik bir araştırma. Anemon Muş Alparslan Üniversitesi Sosyal Bilimler Dergisi, 6(2), 279-286. https://doi.org/10.18506/anemon.325977

Erdem, F., \& İşbaşı, Ö. J. (2001). Eğitim kurumlarında örgüt kültürü ve öğrenci alt kültürünün algılamaları. Akdeniz I.I.B.F. Dergisi, 1, 33-57, internet adresi: http://www.akdeniz.edu.tr/iibf/dergi/Sayi01/Erdem.pdf

Eren, E., \& Uluuysal, B. (2012). Bilişim teknolojileri (BT) öğretmenlerinin mesleki sorunları ve çözüm önerileri: Okul müdürü ve BT öğretmenlerinin görüşleri. Mersin Üniversitesi Ĕgitim Fakültesi Dergisi, 8(3), $152-171$.

Eriş, H. M., \& Anıl, D. (2015). Üniversite öğrencilerinin yaşam kalitesi düzeylerinin bazı değişkenlere göre incelenmesi (pp. 1-14). Hacettepe Üniversitesi Eğitim Fakültesi Dergisi. https://doi.org/10.16986/HUJE.2015014183

Eser, E., Fidaner, H., Fidaner, C., Eser, S. Y., Elbi, H., \& Göker, E. (1999). WHOQOL-100 ve WHOQOL-BREF'in psikometrik özellikleri. Psikiyatri Psikoloji Psikofarmakoloji (3P) Dergisi, 7(Suppl 2), 23-40.

Fine, M. (1986). Why urban adolescents drop into and out of public school. Teachers College Record, 87, 393-409.

Fraser, B. J. (2012). Classroom environment (Vol. 234). Routledge. https://doi.org/10.4324/9780203125885

Fujisawa, M., Ichikawa, Y., Yoshiya, K., Isotani, S., Higuchi, A., Nagano, S., ... Kamidono, S. (2000). Assessment of health-related quality of life in renal transplant and hemodialysis patients using the SF-36 health survey. Urology, 56(2), 201-206. https://doi.org/10.1016/S0090-4295(00)00623-3

Gholami, A., Jahromi, L. M., Zarei, E., \& Dehghan, A. (2013). Application of WHOQOL-BREF in measuring quality of life in health-care staff. International Journal of Preventive Medicine, 4(7), 809.

Güler, D. (2006). Mastalji, Yaşam Kalitesi ve Depresyon (pp. 64-65). Uzmanlık Tezi, Sağlık Bakanlığı Şişli Etfal ve Araştırma Hastanesi, Aile Hekimliği, İstanbul.

Humar, A., Denny, R., Matas, A. J., \& Najarian, J. S. (2003). Graft and quality of life outcomes in older recipients of a kidney transplant. Experimental and Clinical Transplantation: Official Journal of the Middle East Society for Organ Transplantation, 1(2), 69-72.

Kabeta, M. H. (1999). University productive sector linkages for quality of life improvement. Institute of Distance Education, 112.

Karatzias, A., Power, K. G., \& Swanson, V. (2001). Quality of school life: Development and preliminary standardisation of an instrument based on performance indicators in Scottish secondary schools. School Effectiveness and School Improvement, 12(3), 265-284. https://doi.org/10.1076/sesi.12.3.265.3449

Keser, H., \& Çetinkaya, L. (2013). Professional problems experienced by information technology teachers and suggested solutions: Longitudinal survey. Turkish Online Journal of Qualitative Inquiry, 4(2), 1-17.

Kılıç, S. (2016). Cronbach’ın alfa güvenirlik katsayısı. Journal of Mood Disorders, 6(1), 47-48. https://doi.org/10.5455/jmood.20160307122823 
Linnakylä, P., \& Brunell, V. (1996). Quality of school life in the Finnish and Swedish speaking schools in Finland. Reading Literacy in an International Perspective, 203-217.

Low, L. (2000). Are college students satisfied? A national analysis of changing expectations (pp. 29-33). New Agenda Series [TM]. Indianapolis: USA Group Inc.

Malin, A., \& Linnakylä, P. (2001). Multilevel modelling in repeated measures of the quality of Finnish school life. Scandinavian Journal of Educational Research, 45(2), 145-166. https://doi.org/10.1080/00313830120052732

Marcoulides, G. A., Heck, R. H., \& Papanastasiou, C. (2005). Student perceptions of school culture and achievement: Testing the invariance of a model. International Journal of Educational Management, 19(2), 140-152. https://doi.org/10.1108/09513540510582435

Marks, G. N. (1998). Attitudes to School Life: Their Influences and Their Effects on Achievement and Leaving School. Australia: Australian Council for Educational Research Ltd.

MEB Yenilik ve Eğitim Teknolojileri Genel Müdürlüğü. (2012). Bilişsim teknolojileri rehberliği görevi (28.09.2012 tarih ve B.08.0.YET.0.10.04.00-903.99/16791 say1l yaz1).

Mok, M. M. C., \& Flynn, M. (2002). Determinants of Students' Quality of School Life: A Path Model. Learning Environments Research, 5, 275-300. https://doi.org/10.1023/A:1021924322950

Newcomb, M. D., Bentler, P. M., \& Collins, C. (1986). Alcohol use and dissatisfaction with self and life: A longitudinal analysis of young adults. The Journal of Drug Issues, 16(4), 479-494. https://doi.org/10.1177/002204268601600401

Numanoğlu, G., \& Şen, B. (2007). Learning styles of university students attending department of computer and instructional technologies education. Ahi Evran University Kırşehir Educational Faculty Journal, 8(2), 129-148.

Ponton, P., Rupolo, G. P., Marchini, F., Feltrin, A., \& Perin, N. (2001). Quality-of-life change after kidney transplantation. Transplantation $\quad$ Proceedings, 33(1-2), 1887-1889. https://doi.org/10.1016/S0041-1345(00)02737-8

Porter, A. C. (1994). National standards and school improvement in 1990s: Issues and Promise. American Journal of Education, 102, 421-449. https://doi.org/10.1086/444081

Ren, W. (2009). A research on the subject wellbeing of regional college students. International Journal of Psychological Studies, 1(1), 51-53. https://doi.org/10.5539/ijps.v1n1p51

Rui, Y. (1997). College student culture in contemporary China: An analysis. International Education, 26.

Salıcı, O. (2010). Beden eğitimi ve spor yüksekokulu öğrencilerinin üniversitedeki yaşam kalitesine ilişkin algllarının demokratik yaşam kültürü çerçevesinde değerlendirilmesi. Yayımlanmış Yüksek Lisans Tezi, Çukurova Üniversitesi Sağlık Bilimleri Enstitüsü, Beden Eğitimi ve Spor Anabilim Dalı, Adana.

Samsa, S., Bardakçı, S., Alakurt, T., \& Akyüz, H. İ. (2010). Social, Legal and Professional Issues of Information and Communication Technology Teachers in Türkiye. In 9th International Internet Education Conference \& Exhibition, Kahire/Misır.

Schwenk, T. L., Gorenflo, D. W., Dopp, R. R., \& Hipple, E. (2007). Depression and pain in retired professional football players. Medicine and Science in Sports and Exercise, 39(4), 599-605. https://doi.org/10.1249/mss.0b013e31802fa679

Sönmezoğlu, U., Gökçe, H., \& Karakaş, G. (2020). Pamukkale Üniversitesi Öğrencilerinin Yaşam Kalitesi, Örgütsel İmaj ve Özdeşleşme Düzeyleri Arasındaki İlişkilerin İncelenmesi. MANAS Sosyal Araştırmalar Dergisi, 9(3), 1803-1819. https://doi.org/10.33206/mjss.548872

Telatar, T. G., \& Üner, S. (2020). Hemşirelik Öğrencilerinin Yaşam Kalitelerinin ve Algılanan Sosyal Destek Düzeylerinin Belirlenmesi ve Yaşam Kalitesi ile İlişkili Faktörlerin Değerlendirilmesi. Türkiye Klinikleri, 5(1), 128-134. https://doi.org/10.5336/healthsci.2019-66332

Wang, X., Matsuda, N., Ma, H., \& Shinfuku, N. (2000). Comparative study of quality of life between the Chinese and Japanese adolescent populations. Psychiatry and Clinical Neurosciences, 54, 147-152. https://doi.org/10.1046/j.1440-1819.2000.00650.x

World Health Organization. (1997). The world health organization quality of life instruments (The whoqol-100 and the whoqol-bref). Whoqol Measuring Quality of Life, Programme on Mental Health Division of Mental 
Health and Prevention of Substance Abuse.

Yazıcı, M. (2012). Spor yapan ve yapmayan ampute bireylerin yaşam kalitesi ve depresif durumlarının incelenmesi. Yayımlanmamış doktora tezi. Ondokuz Mayıs Üniversitesi Sağlık Bilimleri Enstitüsü Beden Eğitimi ve Spor Anabilim Dalı, Samsun.

Yıldırım, A., \& Hacıhasanoğlu, R. (2011). Sağlık çalışanlarında yaşam kalitesi ve etkileyen değişkenler. Psikiyatri Hemşireliği Dergisi, 2(2), 61-68.

Zhang, Y., Qu, B., Lun, S., Wang, D., Guo, Y., \& Liu, J. (2012). Quality of life of medical students in China: a study using the WHOQOL-BREF. PloS One, 7(11), e49714. https://doi.org/10.1371/journal.pone.0049714

\section{Copyrights}

Copyright for this article is retained by the author, with first publication rights granted to the journal.

This is an open-access article distributed under the terms and conditions of the Creative Commons Attribution license (http://creativecommons.org/licenses/by/4.0/). 